\title{
Pembangunan Sistem Manajemen Armada pada PT. Kino Indonesia Tbk
}

\author{
Lidya Siti Hafsari $^{1^{*}}$, Tacbir Hendro Pudjiantoro ${ }^{2}$, Irma Santikarama ${ }^{3}$ \\ ${ }^{1,2,3}$ Jurusan Informatika, Fakultas Sains Dan Informatika, \\ Universitas Jenderal Achmad Yani \\ Jl. Terusan Jend.Sudirman, Cibeber, Kecamatan Cimahi Sel., Kota Cimahi, Jawa Barat 40531. \\ *Email: lidyasitihafsari06@gmail.com, tacbir.hendro@lecture.unjani.ac.id, \\ irma.santikarama@lecture.unjani.ac.id
}

\begin{abstract}
Abstrak
Manajemen armada merupakan kegiatan operasional perusahaan untuk layanan angkutan orang ataupun barang, manajemen armada dilakukan untuk memperoleh informasi seperti jarak yang ditempuh, tujuan yang dicapai, perbaikan serta pemeliharaan dan perencanaan servis berkala. Penelitian sebelumnya telah menunjukkan bahwa banyak penelitian mengenai manajemen armada tetapi penelitian tersebut dilakukan sebagian besar fokus pada salah satu modul manajemen armada. Sistem manajemen armada ini menerapkan beberapa modul seperti routing, shipment management dan vehicle management. Dalam studi ini, peneliti mencoba untuk menerapkan sistem manajemen armada pada PT Kino yang memiliki 30 armada tetapi terdapat masalah yaitu perkiraan waktu pengiriman tidak dapat dipantau dikarenakan perusahaan tidak mempunyai perencanaan rute yang tepat dalam setiap pengiriman yang mengakibatkan optimalisasi rute dengan tata letak barang pada armada tidak terstruktur, sehingga perusahaan tidak kunjung mempunyai perencanaan rute yang optimal untuk pencapaian perusahaan. Selanjutnya perusahaan sulit memonitoring armada saat proses pengiriman barang, hal ini dikarenakan proses yang berjalan masih dilakukan secara minimalis yang mengakibatkan adanya data laporan berbeda antara pelanggan dan bagian pengiriman. Setelah melakukan pembangunan sistem yang dibutuhkan, tes penerimaan pengguna dilakukan dengan hasil sebesar $83.95 \%$ dari 41 kasus uji yg dilakukan oleh 6 aktor. Untuk pengembangan sistem manajemen armada ini maka disarankan agar dapat melakukan live tracking menggunakan Maps.
\end{abstract}

Kata kunci: data, manajemen armada, monitoring, routing

\section{PENDAHULUAN}

Manajemen armada (fleet management) merupakan kegiatan yang relevan di tingkat operasional yang harus dihadapi perusahaan swasta dan lembaga publik yang ditujukan untuk layanan angkutan penumpang atau angkutan barang (Bielli et al, 2015). Dalam penggunaannya baik perusahaan swasta ataupun lembaga publik harus mengetahui bagaimana melakukan pengelolaan armada, agar mereka dapat memastikan armada yang akan digunakan untuk kegiatan operasional ataupun perjalan dinas dapat berjalan secara optimal (Ayunda 2018). Sistem Manajemen Armada (Fleet Management System) dibuat dengan terstruktur agar memungkinkan perusahaan mendapatkan informasi pada berbagai aspek seperti dalam penggunaan, pemeliharaan, dan operasional armada. Informasi yang perlu didapatkan antara lain jarak yang ditempuh, tujuan yang dicapai, perbaikan serta pemeliharaan dan perencanaan servis berkala armada. Laporan dapat dihasilkan setiap seminggu sekali, dua minggu sekali, satu bulan sekali, sesuai dengan kebutuhan (Yudianto dkk, 2017).

Penerapan sistem manajemen armada (fleet management system) sangat berguna bagi perusahaan BUMN (Badan Usaha Milik Negara) salah satunya PT PLN (Persero) dimana dalam proses penerapan fleet management system ini perusahaan dapat mengoptimalkan pengelolaan armada dinas sehingga mampu memberikan pelayanan yang lebih cepat (Masrur dkk, 2015). Selain pada perusahaan yang dikelola oleh negara penerapan fleet management system juga sangat berguna bagi perusahaan swasta seperti pada PT Roda Pembina Nusantara dimana sebelumnya pendokumentasian pemeliharaan dan perbaikan kendaraan masih belum terdokumentasi dengan baik, sehingga informasi yang dibutuhkan untuk pemeliharaan dan perbaikan kendaraan menjadi kurang 
akurat. Dengan dibuatkannya sistem informasi pengelolaan armada perusahaan dapat mengelola data kendaraan dengan baik dimana dapat merekam hasil transaksi yang dilakukan melakukan pengelolaan kendaraan (Kurniawan dan Awalludin, 2019).

PT Kino Indonesia Tbk memiliki 30 armada yang digunakan untuk melakukan kegiatan distribusi atau penyampaian produk kepada pelanggan (retail dan agen). Pada proses manajemen armada yaitu perencanaan rute yang ada masih terdapat masalah dimana perusahaan melakukan perencanaan rute tersebut dengan cara perkiraan pribadi oleh bagian logistik dimana hal tersebut dapat mengakibatkan adanya informasi yang tidak tersampaikan secara lengkap sehingga tidak terstrukturnya penempatan barang pada armada dapat mengurangi kualitas layanan pada pelanggan, hal lain yang terjadi yaitu perusahaan tidak memiliki laporan target pengiriman dan tidak mengetahui rute optimal untuk pencapaian perusahaan serta perencanaan rute selanjutnya. Permasalah lainnya yaitu perusahaan kesulitan memonitoring proses pengiriman barang yang menyebabkan banyak celah untuk menghilangkan barang yang akan dikirim ke pelanggan (retail dan agen) oleh pihak yang tidak bertanggung jawab yang menyebabkan kerugian bagi perusahaan.

Terdapat metode Saving Matrix yang dapat digunakan untuk penerapan sistem fleet management yang akan membantu dalam perencanaan rute, ketepatan waktu, minimalisasi pembiayaan dan penyimpangan destinasi. Dimana metode saving matrix akan memberikan jarak, rute, waktu atau ongkos dalam pelaksanaan pengiriman barang dari perusahaan kepada konsumen. Metode ini bertujuan agar pengiriman barang yang sesuai pesanan konsumen dapat dilakukan dengan cara yang efektif dan efisien, sehingga perusahaan dapat menghemat biaya, tenaga, dan waktu pengiriman.

Berdasarkan permasalahan diatas dilakukan penelitian dengan membangun sistem manajemen armada yang dapat mengelola armada dengan adanya perencanaan rute pada setiap jadwal pengiriman serta adanya laporan rekap jadwal secara cepat dan tepat tanpa adanya pencatatan ulang dan sistem mampu memonitoring aset dan memberikan laporan hasil monitoring (tracking) agar proses pengelolaan armada dapat dimaksimalkan.

\section{TINJAUAN PUSTAKA \\ 2.1 Perencaaan Rute}

Perencanaan rute digunakan untuk menentukan rencana rute berdasarkan waktu perjalanan normal dan data permintaan tersedia yang menghasilkan perubahan waktu perjalanan serta mempercepat kedatangan pesanan pelanggan baru. Efektivitas rencana rute mempertimbangkan data dinamis dari posisi kendaraan, level muatan dari setiap kendaraan, waktu perjalanan serta status data pesanan pelanggan (Cheung et al, 2015). Pembentukan rute dan alokasi dapat diimplementasikan menjadi dua varian: varian 1- ketika armada masih diperusahaan, varian 2- ketika armada berangkat menggunakan jalur yang telah disediakan (Oleg Shandera, Danylo Shumyka, Yuliya Shandera 2019).

\subsection{Penjadwalan Pengiriman}

Persaingan yang berkembang mendorong perusahaan-perusahaan pengiriman untuk menyediakan layanan ekspres seperti pengiriman hari ini atau hari berikutnya. Layanan tersebut ditawarkan sebagai tanggapan atas pengiriman mendesak dan jadwal dari pelanggan. Untuk itu perusahaan harus melakukan penjadwalkan pengiriman secara efisien dimana memperkenalkan penjadwalan pengiriman ini dapat menahan total biaya. Penjadwalan pengiriman dipengaruhi oleh jenis kendaraan, biaya pemasangan, biaya penyimpanan, dan permintaan (Masaeli et al, 2018).

\subsection{Monitoring}

Monitoring merupakan suatu kegiatan mengamati secara seksama suatu keadaan atau kondisi, termasuk juga perilaku atau kegiatan tertentu, dengan tujuan agar semua data masukan atau informasi yang diperoleh dari hasil pengamatan tersebut dapat menjadi landasan dalam mengambil keputusan.Monitoring memiliki beberapa prinsip, yaitu : dilakukan terus menerus, menjadi umpan terhadap perbaikan sistem, dan memberi manfaat terhadap organisasi maupun terhadap pengguna layanan (Kartakusumah 2019). 


\subsection{Perawatan Armada}

Perawatan armada (Service) adalah masalah penting pada perusahaan, karena kondisi buruk di jalan yang mengakibatkan kerusakan pada armada sangat merugikan yang berdampak pendapatan perusahaan. Efisien melaksanakan layanan service ini adalah yang paling penting untuk meminimalkan risiko kinerja yang signifikan berkurang (Lukman et al, 2018). Reminder service digunakan untuk melakukan pemberitahuan kepada konsumen kegiatan servis (perawatan) berkala, dengan adanya reminder pengurusan berkas serivce dapat menampilkan berkas secara akurat berdasarkan proses tanggal service sebelumnya (Erwan dkk, 2018).

\section{METODE PENELITIAN}

Metode penelitian adalah suatu cara yang dipergunakan untuk melakukan penelitian sehingga mampu menjawab identifikasi masalah dan tujuan penelitian. Adapun tahapan - tahapan penelitian yaitu:

\subsection{Metode Pengumpulan Data}

Pada tahap ini adalah tahapan untuk melakukan pengambilan data terhadap proses distribusi yang berada di PT Kino Indonesia Tbk. Pengumpulan data dilakukan dalam dua cara yaitu observasi dan wawancara.

\section{Observasi}

Observasi merupakan metode pengumpulan data melalui pengamatan langsung atau peninjauan secara cermat di lapangan atau lokasi penelitian. Observasi di PT Kino Indonesia Tbk yang beralamat di Jl. Cibolerang Masgasuka Kec. Babakan Ciparay Kota Bandung dilakukan dengan tujuan memperoleh gambaran yang jelas mengenai proses bisnis yang terjadi, sehingga dapat menemukan solusi untuk memecahkan permasalahan tersebut.

\section{Wawancara}

Wawancara adalah teknik pengumpulan data yang dilakukan dengan mengajukan pertanyaan langsung kepada narasumber terkait dengan proses bisnis pada PT Kino Indonesia Tbk. Narasumber yang diwawancarai di antaranya adalah Sales dan Manager PT Kino Indonesia Tbk untuk memperoleh informasi secara langsung disertai dengan adanya data yang akurat.

\subsection{Metode Penentuan rute menggunakan metode Saving Matrix}

Pada tahap kedua ini yaitu proses perhitungan untuk menentukan jalur/rute dengan cara menentukan jalur yang harus dilalui sesuai dengan jumlah kapasitas dari alat angkut tersebut agar diperoleh jalur yang efisien dan biaya transportasi yang optimum. Pengolahan data pertama yaitu menentukan matrix jarak dilakukan dengan cara perhitungan menggunakan rumus, setelah mendapat olahan data jarak antara lokasi dngan lokasi lain dalam satuan $\mathrm{km}$ maka dilakukan matrix penghematan yaitu menghitung penghematan apabila ada penggabungan rute yang dinilai satu arah dan tahap terakhir yaitu menentukan urutan rute.

Metode saving matrix dilakukan pada pendistribusian produk dengan tujuan untuk membuat jadwal pengiriman produk lebih efisien dan pengalokasian produk ke setiap armada yang tersedia dilakukan secara tepat dengan tidak melebihi kapasitas armada dengan memberikan rute yang memiliki waktu penghematan terbesar. Diketahui armada yang tersedia terdapat 2 armada yaitu mobil colt dengan kapasitas 600, dimana data customer beserta order dapat dilihat pada Tabel 1 .

Tabel 1. Data Order Customer

\begin{tabular}{ccc}
\hline No & Nama & Order \\
\hline 1. & Deni (c1) & 50 \\
2. & Raka (c2) & 135 \\
3. & Wanda (c3) & 150 \\
4. & Aris (c4) & 120 \\
5. & Wina (c5) & 60 \\
\hline
\end{tabular}

1. Menentukan Matrix Jarak menyatakan jarak diantara tiap pasangan lokasi yang harus dikunjungi. Menentukan jarak dapat menggunakan google earth, google maps maupun melakukan perhitungan manual. Adapun disini saya menggunakan google maps yang mana menentukan matriks jarak dapat dilihat pada Tabel 2.

Tabel 2. Menentukan Matrix Jarak

\begin{tabular}{lllllll}
\hline & Gudang & C1 & C2 & C3 & C4 & C5 \\
\hline C1 & 15.70 & 0.0 & & & & \\
C2 & 1.92 & 15.75 & 0.0 & & & \\
C3 & 3.18 & 14.18 & 2.05 & 0.0 & & \\
C4 & 3.56 & 13.77 & 2.45 & 0.40 & 0.0 & \\
C5 & 3.29 & 14.04 & 1.88 & 0.13 & 0.29 & 0.0 \\
\hline
\end{tabular}

2. Menentukan Matrix Penghematan menunjukkan penghematan yang terjadi jika menggabungkan dua toko customer yang 
memungkinkan ke dalam satu armada sehingga dapat dilakukan penghematan jarak, waktu dan biaya transportasi. Dimana persamaan untuk mencari penghematan seperti dibawah ini :

$$
\begin{aligned}
& S(x, y)=J(x, y)+J(\tilde{x}, y)-J(x, y) \\
&- S(1,2)=15,70+1.92-15.75=1.87 \\
&- S(1,3)=15.70+3.18-14.18=4.7 \\
&- S(2,3)=1.92+3.18-2.05=3.05 \\
&-\quad S(1,4)=15.70+3.56-13.77=5.49 \\
&-\quad S(2,4)=1.92+3.56-2.45=3.03 \\
&-\quad S(3,4)=3.18+3.56-0.40=6.34 \\
&-\quad S(1,5)=15.70+3.39-14.04=5.05 \\
&-\quad S(2,5)=1.92+3.29-1.88=3.33 \\
&-\quad S(3,5)=3.18+3.29-0.13=6.34 \\
&-\quad S(4,5)=3.56+3.29-0.29=6.56
\end{aligned}
$$

Setelah menggunakan cara diatas, maka dapat diperoleh matrix penghematan yang dapat dilihat pada Tabel 3 .

Tabel 3. Matrix Penghematan

\begin{tabular}{llllll}
\hline & C1 & C2 & C3 & C4 & C5 \\
\hline C1 & 0.0 & & & & \\
C2 & 1.87 & 0.0 & & & \\
C3 & 4.07 & 3.05 & 0.0 & & \\
C4 & 5.49 & 3.03 & 6.34 & 0.0 & \\
C5 & 5.05 & 3.33 & 6.34 & 6.56 & 0.0 \\
\hline
\end{tabular}

3. Pengalokasian masing-masing konsumen kedalam armada dan menentukan rute berdasarkan lokasi

a. Iterasi 1 : dari tabel 3.9, diperoleh penghematan tertinggi sebesar $6.56=$ $\mathrm{S}(4,5)$ dengan menggabungkan rute untuk customer 4 dan customer 5 dalam satu rute. Selanjutnya dilakukan pengecekan apakah penggabungan tersebut layak dilakukan atau tidak. Beban yang dibawa dengan penggabungan ini yaitu $120+60=180$ $(<600)$ dengan demikian rute ini layak digabungkan.

b. Iterasi 2 : dari tabel 3.9, diperoleh penghematan tertinggi berikutnya sebesar $6.34=\mathrm{S}(3,4)$ dan $\mathrm{S}(3,5)$ dengan menggabungkan rute pertama yaitu customer 3 dan customer 4 selanjutnya customer 3 dan customer 5 . Karena dari iterasi sebelumnya rute untuk customer 4 dan customer 5 sudah tetap maka yang terjadi kita lihat apakah customer 3 dapat digabungkan dengan rute tersebut, dimana beban untuk rute tersebut menjadi $120+60+150=330(<600)$ dengan demikian customer 3 dapat dimasukkan ke dalam rute yang sudah tetap.

c. Iterasi 3 : dari tabel 3.9, diperoleh penghematan berikutnya sebesar $5.49=$ $\mathrm{S}(1,4)$ dengan menggabungkan rute untuk customer 1 dan customer 4 . Karena dari iterasi sebelumnya rute untuk customer 4 sudah tetap maka yang terjadi kita lihat apakah customer 1 dapat digabungkan dengan rute tersebut, dimana beban untuk rute tersebut menjadi $120+60+150+50=380$ $(<600)$ dengan demikian customer 1 dapat dimasukkan ke dalam rute yang sudah tetap.

d. Iterasi 4 : dari tabel 3.9, diperoleh penghematan berikutnya sebesar $5.05=$ $\mathrm{S}(1,5)$ dengan menggabungkan rute untuk customer 1 dan customer 5. Dari iterasi sebelumnya dapat dilihat bahwa customer 1 dan customer 5 sudah masuk dalam rute.

e. Iterasi 5 : dari tabel 3.9, diperoleh penghematan berikutnya sebesar $4.7=$ $\mathrm{S}(1,3)$ dengan menggabungkan rute untuk customer 1 dan customer 3. Dari iterasi sebelumnya dapat dilihat bahwa customer 1 dan customer 3 sudah masuk dalam rute.

f. Iterasi 6 : dari tabel 3.9, diperoleh penghematan berikutnya sebesar $3.33=$ $\mathrm{S}(2,5)$ dengan menggabungkan rute untuk customer 2 dan customer 5. Karena dari iterasi sebelumnya rute untuk customer 5 sudah tetap maka yang terjadi kita lihat apakah customer 2 dapat digabungkan dengan rute tersebut, dimana beban untuk rute tersebut menjadi $120+60+150+50+85=465$ $(<600)$ dengan demikian customer 2 dapat dimasukkan ke dalam rute yang sudah tetap.

Diperoleh satu rute yaitu 4,5,3,1,2 yang berarti hanya menggunakan 1 mobil colt untuk melayani/mengirimkan barang ke customer.

4. Pengurutan lokasi tujuan dalam suatu rute, pengurutan lokasi pengiriman yang terdiri dari konsumen 4,5,3,1 dan 2 kedalam rute menggunakan prosedur Nearest Neighbour yang menitik beratkan pada jarak terdekat 
dari perusahaan dan selanjutnya mengutamakan lokasi yang jaraknya paling dekat dengan lokasi yang dikunjungi terakhir. Sehingga diperoleh rute $\mathrm{G} \rightarrow 2 \rightarrow$ 5 -> $3 \rightarrow 4 \rightarrow 1 \rightarrow G$ dimana untuk menentukan panjang jarak dapat dilihat pada tabel 2 sehingga diperoleh panjang jarak $1.92+1.88+0.13+0.40+13.77+15.70=$ $33.8 \mathrm{~km}$.

\subsection{Metode Pengembangan Sistem}

Dalam perancangan aplikasi ini, penulis mengimplementasikan metode Waterfall atau classic life cycle sebagai metode pengembangan perangkat lunak yang meliputi tahap :
1. Analisa Kebutuhan (Analysis)
2. Desain Sistem (Design)
3. Pemrograman (Coding)
4. Pengujian (Testing)

Pemodelan sistem dilakukan dengan menggunakan metode UML yang meliputi usecase diagram, sequence diagram dan class diagram.

\section{HASIL DAN PEMBAHASAN}

Hasil dari penelitian ini yaitu Sistem Manajemen Armada yang dapat menampilkan laporan rekap pesanan secara realtime, menampilkan jadwal dengan memberikan rute optimal distribusi dan laporan rekap jadwal serta memonitoring proses pengiriman barang.

\subsection{Kebutuhan Sistem}

Tahapan ini didapatkan dari hasil pengumpulan data yang dijelaskan pada langkah metode penelitian dimana setelah dianalisa sistem manajemen armada ini memiliki enam aktor yaitu super admin, pelanggan, administrasi, admin $\mathrm{AE}$, logistik serta manager.

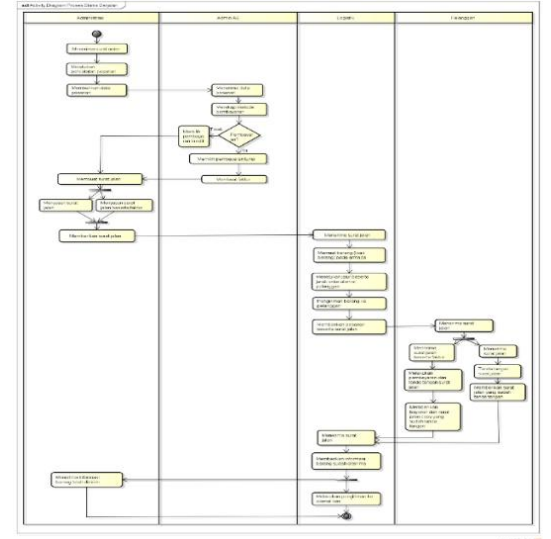

Gambar 1. Alur Proses Sistem
Alur sistem yang akan dijalankan oleh setiap aktor digambarkan dalam bentuk activity diagram yang ditunjukkan pada Gambar 1.

Pelanggan melakukan pemesanan dengan menentukan pilih pesanan serta metode pembayaran yang akan digunakan, setelah pelanggan melakukan submit pesanan maka daftar pesanan akan masuk ke bagian administrasi. Administrasi akan melakukan pengecekan apakah pelanggan yang melakukan pemesanan pernah melakukan pemesanan atau belum, dan jika pernah apakah masih ada piutang atau tidak. Setelah administrasi melakukan persetujuan pesanan maka admin AE akan membuatkan faktur bagi pelanggan yang melakukan pemesanan dengan metode pembayaran cash. Selanjutnya administrasi akan membuat jadwal distribusi dimana pada bagian ini akan dilakukan perhitungan dengan metode saving matrix yang akan menghasilkan jadwal pengiriman hari A dengan armada A dan rute yang akan dilalui. Setelah jadwal dibuat maka administrasi akan membuat surat faktur sesuai rute yang akan dilewati.

Logistik melakukan pengiriman sesuai rute yang telah ditentukan dimana pada setiap titik penurunan barang logistik diharuskan update tracking dengan melakukan konfirmasi bahwa barang telah diterima oleh pelanggan serta mengirimkan bukti konfirmasi sebagai penanda barang telah terkirim.

Kebutuhan pengguna serta kebutuhan dari alur proses yang telah dijelaskan diatas di dalam sebuah sistem disebut dengan kebutuhan fungsional. Dimana kebutuhan sistem yang dibangun : Kelola Pengguna, Kelola Pelanggan, Kelola Pemesanan Beverage, Kelola Pemesanan Non Food, Daftar Pesanan, Kelola Armada, Kelola Jadwal Distribusi, Kelola Surat Jalan, Kelola Tracking, Kelola Faktur, Kelola Barang dan Kelola Servis. Dimana setiap pengguna mempunyai role hak akses yang berbeda - beda dalam mengoperasikan sistem ini, untuk lebih jelasnya lagi dapat dilihat pada use case pada gambar 2 . 


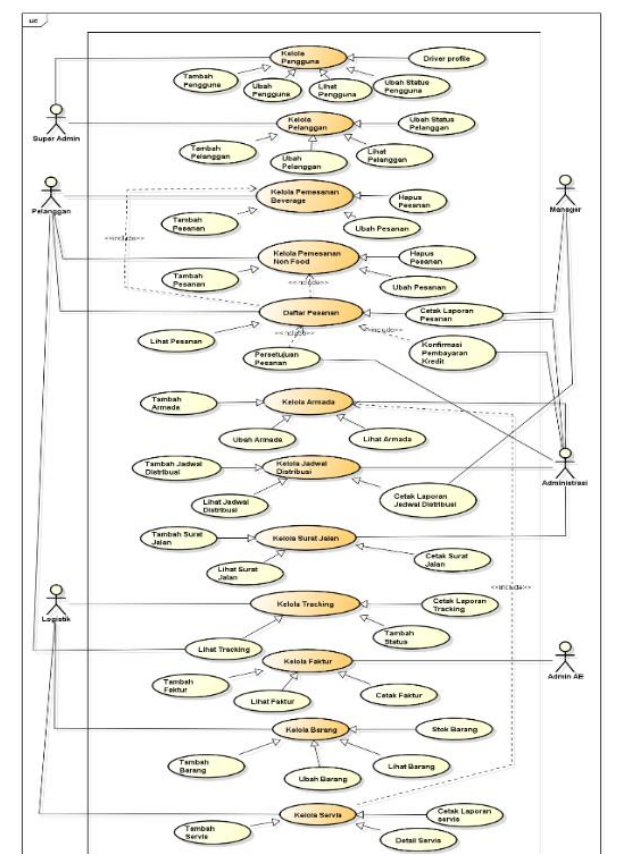

Gambar 2. Use Case Diagram

\subsection{Implementasi dan Pengujian}

Tahap implementasi adalah tahap untuk mengimplementasikan dari tahap analisa kebutuhan yang sudah dilakukan. Implementasi dilakukan menggunakan Bahasa Pemrograman PHP dengan framework CI (Code Igniter) serta sarana penyimpanan data yaitu database MySQL.

Desain interface ditunjukkan pada gambar 3,4,5,6,7,8,9 dan 10 dimana Halaman pertama yaitu halaman login. Halaman login digunakan oleh setiap aktor untuk mengakses sistem dengan memberikan keamanan otoritas dan membedakan hak akses setiap aktor.

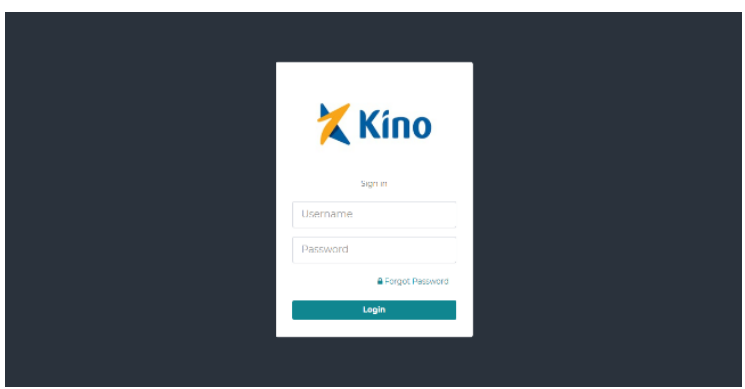

Gambar 3. Halaman Login

Halaman Kelola Pesanan adalah halaman yang hanya dapat diakses oleh pelanggan hak akses dalam sistem ini adalah menambah, mengubah dan menghapus pesanan jika belum dilakukan persetujuan oleh admin.

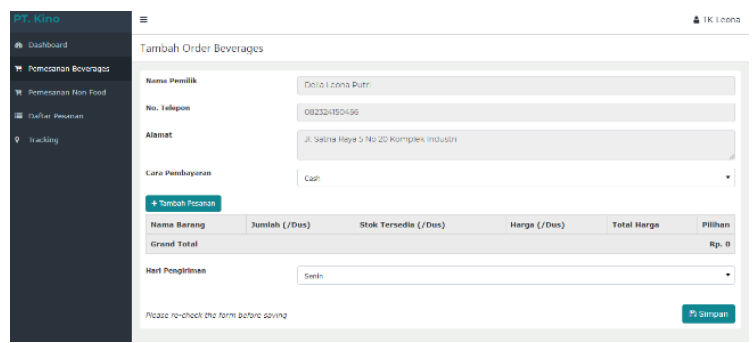

Gambar 4. Halaman Kelola Pesanan

Halaman Daftar Pesanan adalah halaman yang dapat diakses oleh administrasi hak aksesnya yaitu persetujuan pesanan, konfirmasi pembayaran kredit dan cetak laporan.

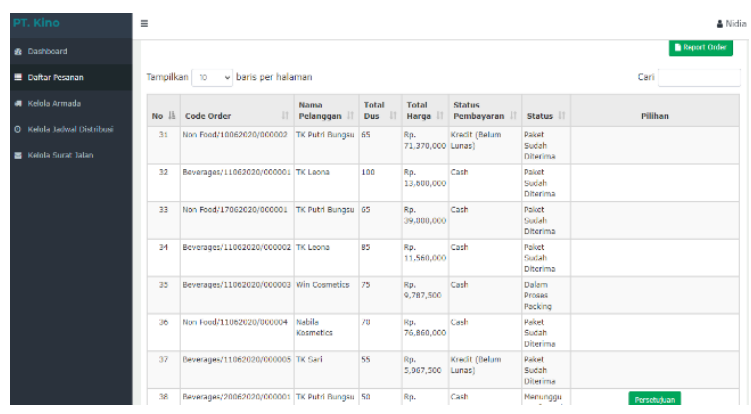

Gambar 5. Halaman Daftar Pesanan

Halaman Kelola Jadwal Distribusi adalah halaman yang dapat diakses oleh administrasi dimana hak akses dalam sistem ini adalah menambahkan jadwal, melihat detail jadwal dan cetak laporan.
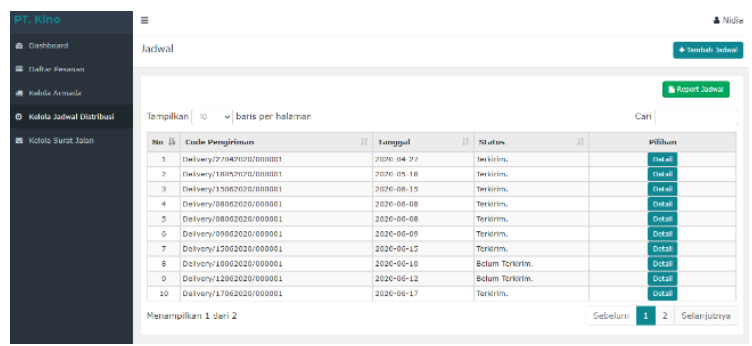

Gambar 6. Halaman Jadwal Distribusi

Halaman Perhitungan Metode Saving Matrix adalah halaman perhitungan metode Saving Matrix dimana akan ditampilkan tabel perhitungan serta rute optimal pada jadwal tersebut. 

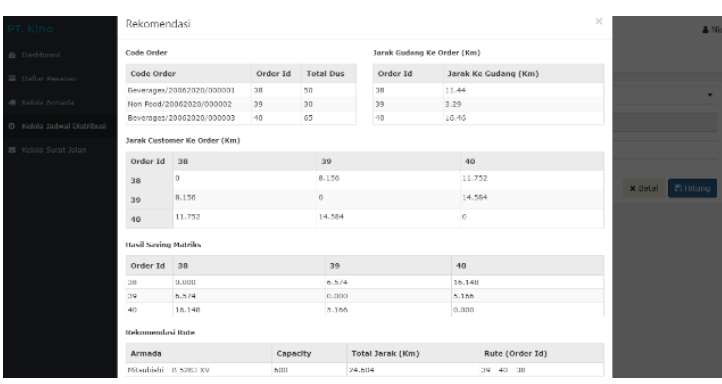

Gambar 7. Halaman Perhitungan Metode Saving Matrix

Halaman Kelola Tracking adalah halaman yang dapat diakses oleh logistik dimana akan ditampilkan urutan rute sesuai perhitungan yang telah dilakukan. Dimana hak akses dalam sistem ini adalah menambah, melihat dan cetak laporan.
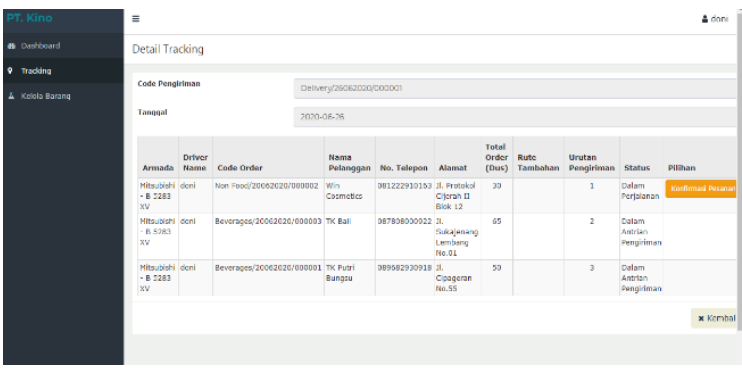

Gambar 8. Halaman Detail Pengiriman

Halaman Laporan adalah halaman yang dapat diakses oleh administrasi, manager serta logistik dimana hak akses dalam sistem ini adalah melakukan cetak laporan atau download laporan. Laporan jadwal menampilkan grafik jadwal pengiriman yang dilakukan perhari, perbulan dan pertahun.
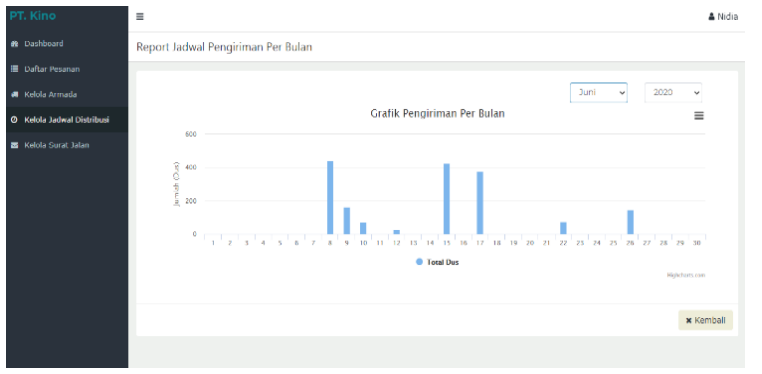

Gambar 9. Halaman Laporan Jadwal Distribusi

Laporan tracking data pengirimanyaitu rute yang dilakukan bagian logistik tersebut yang dilakukan perhari.

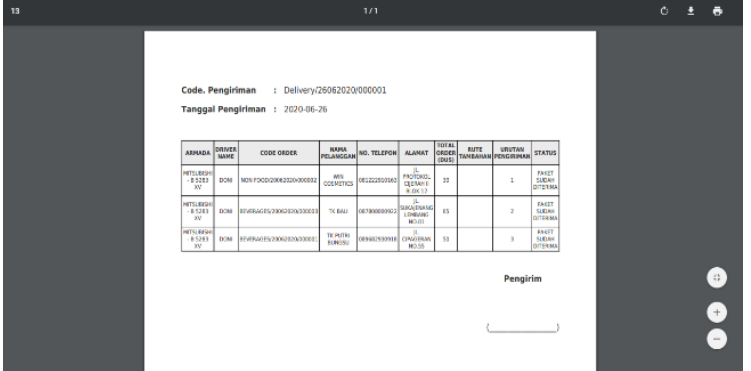

Gambar 10. Halaman Laporan Tracking

Sistem yang telah direalisasikan dengan source code sebagai suatu program utuh dilakukan pengujian pada setiap unit untuk memenuhi spesifikasi kebutuhan fungsional yang sudah ditetapkan. Pengujian dilakukan secara bertahap dari unit satu ke unit berikutnya. Modul yang telah selesai akan diuji untuk mengecek kegagalan dan kesesuaian hasil yang diharapkan. Pengujian yang dilakukan menggunakan Black Box Testing, User Acceptance Test (UAT) dan White Box Testing. Setiap modul diuji oleh pelanggan sebagai pengguna eksternal, manager, super admin, staf administrasi, staf admin AE dan staf logistik sebagai pengguna internal. Hasil pengujian Black Box dapat dilihat pada Tabel 4.

Tabel 4. Pengujian Black Box

\begin{tabular}{|c|c|c|c|}
\hline $\begin{array}{l}\mathbf{N} \\
\mathbf{0}\end{array}$ & Modul Uji & Pengguna & $\begin{array}{c}\text { Keberh } \\
\text { asilan }\end{array}$ \\
\hline 1. & Isi form login & $\begin{array}{l}\text { Seluruh } \\
\text { pengguna }\end{array}$ & $100 \%$ \\
\hline 2. & $\begin{array}{l}\text { Mengelola data } \\
\text { seluruh pengguna } \\
\text { dan pelanggan }\end{array}$ & $\begin{array}{l}\text { Super } \\
\text { Admin }\end{array}$ & $100 \%$ \\
\hline 3. & $\begin{array}{l}\text { Melakukan } \\
\text { pemesanan produk }\end{array}$ & Pelanggan & $100 \%$ \\
\hline 4. & $\begin{array}{l}\text { Mengelola dan } \\
\text { membuat laporan } \\
\text { pemesanan masuk }\end{array}$ & $\begin{array}{l}\text { Staf } \\
\text { Administrasi }\end{array}$ & $100 \%$ \\
\hline 5. & Mengelola Armada & $\begin{array}{l}\text { Staf } \\
\text { Administrasi }\end{array}$ & $100 \%$ \\
\hline 6. & $\begin{array}{l}\text { Mengelola jadwal } \\
\text { dan membuat } \\
\text { laporan jadwal } \\
\text { distribusi }\end{array}$ & $\begin{array}{l}\text { Staf } \\
\text { Administrasi }\end{array}$ & $100 \%$ \\
\hline 7. & $\begin{array}{l}\text { Mengelola surat } \\
\text { jalan }\end{array}$ & $\begin{array}{l}\text { Staf } \\
\text { Administrasi }\end{array}$ & $100 \%$ \\
\hline 8. & Mengelola faktur & $\begin{array}{l}\text { Staf Admin } \\
\mathrm{AE}\end{array}$ & $100 \%$ \\
\hline 9. & $\begin{array}{l}\text { Mengelola tracking, } \\
\text { servis dan } \\
\text { persediaan barang } \\
\text { digudang }\end{array}$ & Staf Logistik & $100 \%$ \\
\hline
\end{tabular}


UAT (User Acceptance Test) adalah suatu proses pengujian yang dilakukan oleh pengguna dengan hasil output sebuah dokumen uji yang dapat dijadikan bukti bahwa perangkat lunak sudah diterima dan sudah memenuhi kebutuhan yang diminta. User Acceptance Test yang telah dilakukan dapat dilihat pada tabel 5.

Tabel 5. Pengujian UAT

\begin{tabular}{|c|c|c|c|}
\hline $\begin{array}{l}\text { User } \\
\text { atau } \\
\text { Tester }\end{array}$ & $\begin{array}{l}\text { Accepta } \\
\text { nce Rate }\end{array}$ & $\begin{array}{l}\text { Notable } \\
\text { Comments }\end{array}$ & User \\
\hline $\begin{array}{l}\text { Super } \\
\text { Admin }\end{array}$ & $\begin{array}{l}\text { (7 dari 9) } \\
77,8 \%\end{array}$ & $\begin{array}{l}\text { "Akan lebih baik } \\
\text { jika form latitude } \\
\text { dan longitude dapat } \\
\text { terisi secara } \\
\text { otomatis saat } \\
\text { memasukan alamat" }\end{array}$ & Aktor \\
\hline $\begin{array}{l}\text { Pelangg } \\
\text { an }\end{array}$ & $\begin{array}{l}(7 \text { dari } 8) \\
87,5 \%\end{array}$ & $\begin{array}{l}\text { "Tampilan cukup } \\
\text { menarik, tapi lebih } \\
\text { bagus jika code } \\
\text { order sudah tersedia } \\
\text { sehingga tidak perlu } \\
\text { copy-paste code } \\
\text { order lagi jadi } \\
\text { tinggal langsung } \\
\text { lacak order" }\end{array}$ & $\begin{array}{l}\text { Aktor } \\
5\end{array}$ \\
\hline $\begin{array}{l}\text { Admini } \\
\text { strator }\end{array}$ & $\begin{array}{l}(11 \text { dari } \\
12) \\
91,7 \%\end{array}$ & $\begin{array}{l}\text { "Cukup bagus dan } \\
\text { penentuan rute } \\
\text { jadwal mudah } \\
\text { dimengerti, sayang } \\
\text { tampilan dashboard } \\
\text { polos" }\end{array}$ & $\begin{array}{l}\text { Aktor } \\
4\end{array}$ \\
\hline $\begin{array}{l}\text { Admin } \\
\mathrm{AE}\end{array}$ & $\begin{array}{l}(2 \text { dari } 3) \\
66,7 \%\end{array}$ & $\begin{array}{l}\text { "Sangat membantu } \\
\text { dimana saat akan } \\
\text { membuat faktur } \\
\text { data pelanggan } \\
\text { tidak perlu ditulis } \\
\text { ulang, bagusnya } \\
\text { tambah nama pada } \\
\text { tabel yang disajikan } \\
\text { awal" }\end{array}$ & $\begin{array}{l}\text { Aktor } \\
3\end{array}$ \\
\hline Logistik & $\begin{array}{l}(8 \text { dari } 10) \\
80 \%\end{array}$ & $\begin{array}{l}\text { "Tambahkan } \\
\text { notifikasi jika pada } \\
\text { satu hari list } \\
\text { tracking masih ada } \\
\text { yang belum } \\
\text { dikonfirmasi" }\end{array}$ & $\begin{array}{l}\text { Aktor } \\
6\end{array}$ \\
\hline $\begin{array}{l}\text { Manage } \\
\text { r }\end{array}$ & $\begin{array}{l}(2 \text { dari } 2) \\
100 \%\end{array}$ & $\begin{array}{lr}\text { "Modul } & \text { laporan } \\
\text { yang } & \text { disajikan } \\
\text { mudah } & \text { dimengerti } \\
\text { untuk } & \text { membantu } \\
\text { dalam analisa tiap } \\
\text { bulan } \\
\text { tahunnya" }\end{array}$ & $\begin{array}{l}\text { Aktor } \\
1\end{array}$ \\
\hline $\begin{array}{l}\text { Averag } \\
\text { e } \\
\text { Accepta } \\
\text { nce }\end{array}$ & $83,95 \%$ & & \\
\hline
\end{tabular}

Pengujian white box didasarkan pada pengujian dengan melihat source code pada perangkat lunak itu sendiri. Pengujian white box dilakukan untuk meyakinkan semua statement dan kondisi dieksekusi secara optimal. Karena keterbatasan dalam penulisan maka yang disampaikan yaitu pengujian pada function metode_penjadwalan bagian perhitungan saving matrix. Berikut penentuan blok kode program, source code sebagai berikut :

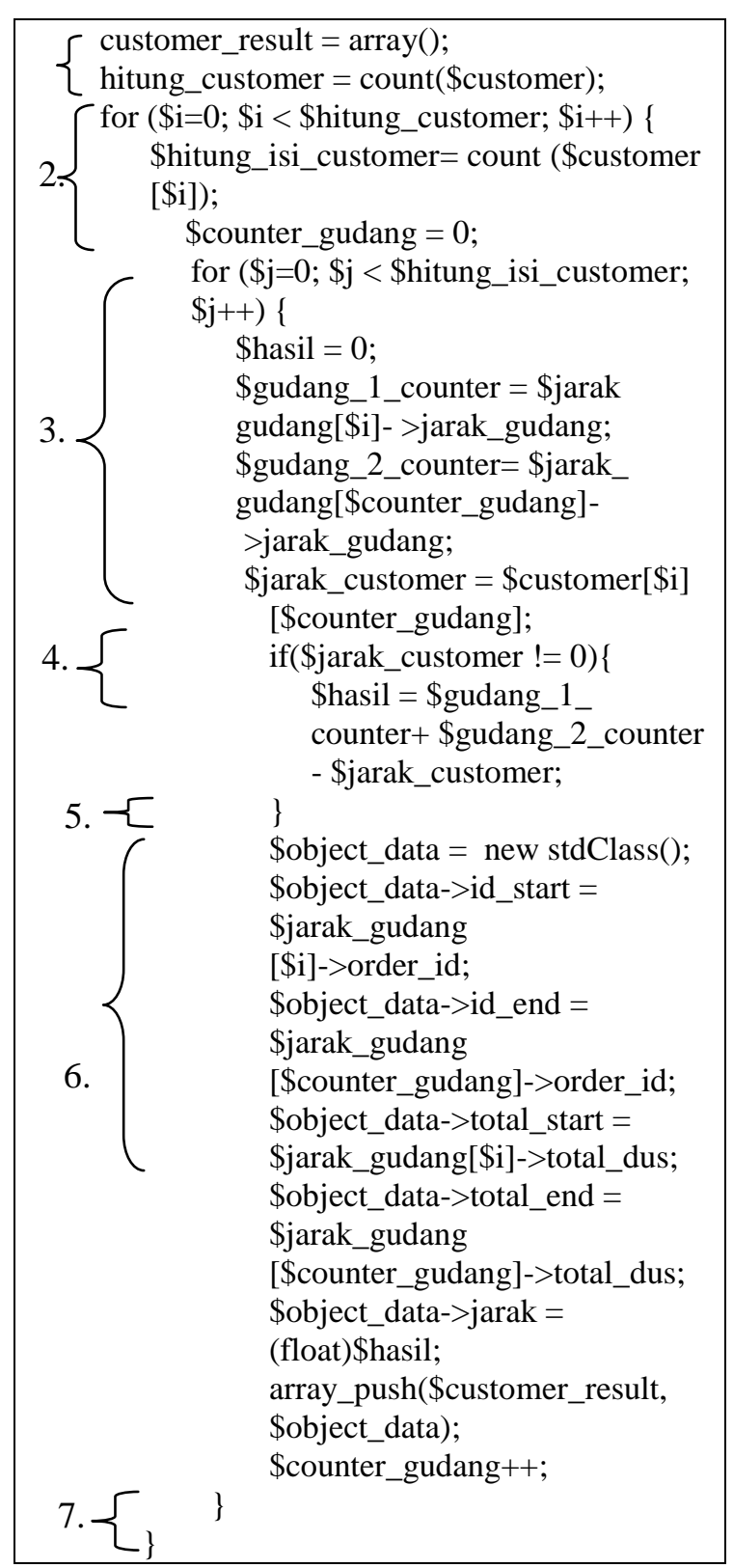

Berikut tampilan source code yang telah diubah menjadi flowgraph dapat dilihat pada gambar 11. 


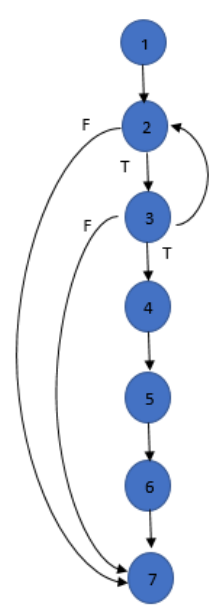

Gambar 11. Flowgrapgh Function metode_penjadwalan bagian saving_matrix

Membuat data uji untuk menunjukkan data yang mungkin dilakukan dalam pengujian dapat dilihat pada Tabel 7.

Tabel 7. Pengujian White Box

\begin{tabular}{|c|c|c|c|}
\hline No & Statement & $\begin{array}{c}\text { Keluaran yang } \\
\text { diharapkan }\end{array}$ & $\begin{array}{c}\text { Keberh } \\
\text { asilan }\end{array}$ \\
\hline 1. & $\begin{array}{l}\text { Mengambil } \\
\text { variabel yaitu } \\
\text { jarak dari } \\
\text { setiap } \\
\text { customer lalu } \\
\text { mengisi hasil } \\
\text { jarak pada } \\
\text { array }\end{array}$ & $\begin{array}{l}\text { Menampilkan } \\
\text { keseluruhan jarak } \\
\text { customer dan } \\
\text { mengisi jarak pada } \\
\text { array }\end{array}$ & $100 \%$ \\
\hline 2. & $\begin{array}{l}\text { Melakukan } \\
\text { pengulangan } \\
\text { untuk mencari } \\
\text { jarak } \\
\text { berdasarkan } \\
\text { index }\end{array}$ & $\begin{array}{l}\text { Menampilkan jarak } \\
\text { berdasarkan index }\end{array}$ & $100 \%$ \\
\hline 3. & $\begin{array}{l}\text { Menentukan } \\
\text { Matrix Jarak } \\
\text { menyatakan } \\
\text { jarak diantara } \\
\text { tiap pasangan } \\
\text { lokasi yang } \\
\text { harus } \\
\text { dikunjungi }\end{array}$ & $\begin{array}{l}\text { Mengahasilkan jarak } \\
\text { customer ke gudang }\end{array}$ & $100 \%$ \\
\hline 4. & $\begin{array}{l}\text { Menentukan } \\
\text { jarak } \\
\text { penghematan }\end{array}$ & $\begin{array}{l}\text { Menghasilkan jarak } \\
\text { penghematan rute } \\
\text { dapat digabungkan } \\
\text { atau tidak }\end{array}$ & $100 \%$ \\
\hline 5. & $\begin{array}{l}\text { Memasukan } \\
\text { hasil dari } \\
\text { penghematan } \\
\text { kedalam array }\end{array}$ & $\begin{array}{l}\text { Menghasilkan } \\
\text { pengalokasian rute }\end{array}$ & $100 \%$ \\
\hline
\end{tabular}

\section{KESIMPULAN}

Setelah dilakukan penelitian, sistem dibuat lalu diuji menggunakan metode black box dan user acceptance test dimana dapat disimpulkan pengguna dapat memahami sistem yang dibuat dengan persentase hampir mendekati $85 \%$. Dimana jika sistem diimplementasikan dapat membantu para aktor dalam masalah yang terjadi di perusahaan dapat dibuktikan dari pengujian tersebut menghasilkan beberapa persentase penerimaan sistem serta masing-masing aktor melakukan penilaian dengan nilai yang sesuai. Sistem akan memberikan informasi pesanan barang dan pelaporan rekap pesanan secara cepat dan efektif, sistem mampu melakukan perencanaan rute optimal sehingga perusahaan mengetahui jalur mana yang dilalui bagian logistik dimana telah disesuaikannya total pengiriman dengan armada sehingga tidak akan terjadi kelebihan muatan dimana perencaan rute tersebut didapatkan dari perhitungan metode saving matrix yang dapat memperoleh rute optimal untuk efesiensi jarak tempuh sehingga perusahaan dapat melakukan penghematan dikarenakan biaya yang perlu dikerluarkan menjadi lebih minimum, sistem mampu melakukan tracking pengiriman untuk meningkatkan pelayanan serta melakukan pemantauan armada jika terjadi sesuatu, hal lain sistem dapat memberikan reminder servis pada setiap armada agar perusahaan dapat memastikan armada yang digunakan berjalan secara optimal. Proses ini dapat menghasilkan laporan pemesanan serta jadwal distribusi yang berbentuk grafik untuk melihat kenaikan dan penurunan pelayanan baik pemesanan atau pengiriman.

\section{DAFTAR PUSTAKA}

Ayunda, (2018), Perancangan Sistem Informasi Manajemen Kendaraan Dalam Memonitoring Kendaraan Dinas Pada Dinass Perhubungan Kota Bekasi, J. Ilm. Sisfotenika, Pp. 1-9.

Bielli M. Bielli A., and Rossi R., (2015), Trends In Models And Algorithms For Fleet Management, Procedia - Soc. Behav. Sci., Vol. 20, Pp. 4-18.

Cheung B. K. S., Choy K. L., Li C. L., Shi W., And Tang J., (2015), Dynamic Routing Model And Solution Methods For Fleet Management With Mobile Technologies, Int. J. Prod. Econ., Vol. 113, No. 2, Pp. 694-705.

Erwan L. V., Yulia Y. dan Rostianingsih S., (2018), Sistem Informasi Administrasi Servis Dan Penjualan Motor Honda Pada $\mathrm{Cv}$ Anugrah Jaya Sumenep, J. Infra Petra, Vol.7 No.1. 
Kartakusumah M. M. F., (2019), Prototype Sistem Monitoring Gardu Distribusi Melalui Sms Gateway Berbasis Mikrokontroler, Vol.14 No.1.

Kurniawan A. dan Awalludin D., (2019), Analisis Dan Perancangan Sistem Informasi Pengelolaan Kendaraan Operasional Berbasis Web Pada Pt Roda Pembina Nusantara, J. Interkom, Vol. 14, No. 1, Pp. 16-23.

Lukman R. K., Cerinšek M., Virtič P., And Horvat B., (2018), Improving Efficient Resource Usage And Reducing Carbon Dioxide Emissions By Optimizing Fleet Management For Winter Services, $J$. Clean. Prod., Vol. 177, No. May 2014, Pp. 1-11.

Masaeli M., Alumur S. A., And Bookbinder J. H., (2018), Shipment Scheduling In Hub Location Problems, Transp. Res. Part B Methodol., Vol. 115, Pp. 126-142.

Masrur M., Mustofa N. A., dan Sofanni M., (2015), Rancang Bangun Sistem Informasi Pengelolaan Kendaraan Di Pt Pln (Persero) Area Mojokerto, Regist. J. Ilm. Teknol. Sist. Inf., Vol. 1, No. 1, P. 24.

Shandera O., Shumyka D., Shander Y., and Ischuka O., (2019), Improving The Technology Of Freight Car Fleet Management Of Operator Company, Procedia Comput. Sci., Vol. 149, Pp. 5056.

Yudianto D. T., Noertjahyana A., dan Andjarwirawan J., (2017), Pembuatan Aplikasi Manajemen Kendaraan Berbasis Android, J. Infra, Vol. Vol 5. 